\title{
PENGARUH KONSENTRASI DAN KECEPATAN PENGADUKAN TERHADAP KARAKTERISTIK MEMBRAN KOMPOSIT CHITOSAN
}

\author{
(INFLUENCE OF CONCENTRATION AND STIRRER SPEED ON \\ CARACTERISTIC OF CHITOSAN COMPOSITE MEMBRANE)
}

\author{
Sri Wahyuni ${ }^{\left.1^{*}\right)}$ dan Alia Damayanti ${ }^{1)}$ \\ Jurusan Teknik Lingkungan \\ Fakultas Teknik Sipil dan Perencanaan \\ Institut Teknologi Sepuluh Nopember Surabaya \\ ${ }^{*}$ E-mail:sri09wahyuni@gmail.com
}

\begin{abstract}
Abstrak
Chitosan (CS) adalah salah satu bahan yang paling banyak digunakan sebagai bahan membran karena memiliki kemampuan yang bagus dalam membentuk film. Namun, masih memiliki beberapa kekurangan karena rapuh dan hidroskopis, sehingga perlu dikombinasikan dengan bahan pendukung seperti Poly (vynil) Alcohol dan Poly (ethilene) Glikol. Penelitian ini dilakukan untuk menganalisis pengaruh konsentrasi penambahan Poly (vynil) Alcohol dan kecepatan pengadukan terhadap karakteristik dan permeabilitas membran. Membran chitosan-Poly (vynil) Alcohol dibuat dengan konsentrasi Poly (vynil) Alcohol sebesar 30\%, 40\%, 50\%, 60\% dan $70 \%$ (v/v). Analisa karakteristik membran dilakukan menggunakan uji tarik. Membran komposit chitosan diujikan pada reaktor cross flow. Pengujian pada reaktor dilakukan selama 50 menit dan permeate diambil setiap 10 menit. Dari penelitian yang telah dilakukan didapatkan kuat tarik pada saat putus meningkat dengan meningkatnya konsentrasi Poly (vynil) Alcohol,hingga konsentrasi $40 \%$ dan dengan peningkatan konsentrasi Poly (vynil) Alcohol lebih lanjut mengakibatkan penurunan pada kuat tarik membran. Kekuatan elastisitas membran pada kecepatan pengadukan $300 \mathrm{rpm}$ lebih besar dibandingkan $100 \mathrm{rpm}$. Nilai fluks tertinggi didapatkan pada variasi konsentrasi membran 30\%, kecepatan pengadukan $100 \mathrm{rpm}$ yaitu sebesar 40,20 $\mathrm{L} / \mathrm{m}^{2}$.jam. Berdasarkan tekanan operasi dan nilai fluks per satuan tekanan dapat disimpulkan bahwa membran komposit yang telah dibuat termasuk dalam membran ultrafiltrasi.
\end{abstract}

Kata kunci: cross flow, fluks, membran chitosan, Poly (ethilene) Glikol, Poly (vynil) Alcohol, uji tarik

\begin{abstract}
Abstrack
Chitosan (CS) is one of the materials that most widely used as a membrane material because it has a good ability for forming the film. However, it has some drawbacks because its fragile and hygroscopic, so it needs to combine with a support material such as Poly (vynil) Alcohol and Poly (ethilene) Glikol. This study was conducted to analyze the effect of the concentration of the addition of Poly (vinyl) Alcohol and stirring speed on the membrane characteristics and permeability. Chitosan-Poly (vynil) Alcohol membranes were produced with 30\%, 40\%, 50\%, 60\% and 70\% (v/v) Poly (vynil) Alcohol concentration. Chitosan composite membrane was tested in cross flow reactor. The reactor testing was condusted for 50 minutes and permeate were taken in every 10 minutes. The research showed that membrane tensile strength values rose with increasing concentrations of Poly (vynil) Alcohol until 40\% concentration and with the further addition of Poly (vynil) Alcohol concentration cause the decrease of membrane tensile strength. The strength of the membranes elasticity with $300 \mathrm{rpm}$ stirring speed are bigger than $100 \mathrm{rpm}$. The highest flux values obtained on 30\% membrane concentration and $100 \mathrm{rpm}$ stirring speed for amount of $40.20 \mathrm{~L} / \mathrm{m}^{2} . \mathrm{hr}$. Based on the operating pressure and flux per unit pressure can be concluded that the composite membrane made was included in the ultrafiltration membrane.
\end{abstract}

Key word: cross flow, flux, chitosan membranne, Poly (ethilene) Glikol, Poly (vinyl) alcohol, tensile strength 


\section{PENDAHULUAN}

Filtrasi membran merupakan teknik pemisahan dua komponen atau lebih tanpa menggunakan panas, komponen-komponen akan terpisah berdasarkan ukuran dan bentuknya, dengan bantuan tekanan dan selaput semi-permeable (Setiawan dkk., 2015). Dalam penggunaannya, bahan baku serta proses pembuatan berperan penting dalam karakteristik dan permeabilitas membran.

Penelitian mengenai pemanfaatan polimer alam sebagai bahan baku pembuatan membran telah banyak berkembang karena polimer alam lebih ramah lingkungan dibandingkan polimer sintetis. Pada umumnya membran yang sering digunakan untuk proses pemisahan adalah membran yang terbuat dari selulosa asetat. Chitosan merupakan suatu polimer alam yang mempunyai struktur mirip dengan selulosa serta dapat dibentuk menjadi film tipis (Meriatna, 2008).Chitosan (CS) adalah salah satu bahan yang paling banyak digunakan sebagai bahan membran karena memiliki kemampuan yang bagus dalam membentuk film, pengolahan mudah dan ketersediaan yang melimpah (Dash et al., 2011). Sebagai contoh, membran chitosan telah digunakan dalam NF desalinasi (Huang et al., 2009), pervaporasi dehidrasi organik (Zhao et al., 2011; Liu et al., 2005), pemisahan gas (Shen et al., 2013), dan bahan bakar sel (Horimatsu et al., 2013. Membran yang terbuat dari chitosan memiliki sifat mekanik yang tidak terlalu baik, diantaranya adalah ketahanannya yang lemah terhadap tarikan dan regangan (Farha dan Kusumawati, 2012).

Berbagai macam penelitian mengenai pengembangan chitosan telah banyak dilakukan, diantaranya modifikasi membran chitosan dengan menggunakan DYT, glutaraldehida, PEG dan PVA. Berdasarkan pada percobaan adsorpsi batch, komposit chitosan/poly (vinyl) alcohol merupakan campuran yang sangat serap untuk ion tembaga (Cheng et al., 2010). Chitosan dan Poly (vynil) Alcohol dengan rantai polimernya dapat berinteraksi secara hidrofobik, agregasi, ikatan hidrogen/intra-molekul. Kinerja yang baik dari chitosan dalam menyerap ion logam berat berhubungan dengan kapabilitas amina chitosan untuk membentuk ikatan kompleks pada permukaan logam berat dalam air. Pori yang terbentuk memberikan media adsorb yang cocok untuk aksesibilitas logam berat. Ini karena resistensi perpindahan massa dalam struktur berpori (Zeng et al., 2004a; Zeng et al., 2004b), sehingga memungkinkan untuk membentuk membran chitosan yang hidrofobik dan kuat.

Penelitian ini dilakukan untuk menganalisis pengaruh konsentrasi penambahan Poly (vynil) Alcohol dan kecepatan pengadukan terhadap karakteristik dan permeabilitas membran. Hasil penelitian tersebut diharapkan dapat menjadi alternatif pengolahan limbah cair sehingga dapat membantu mengatasi masalah pencemaran lingkungan.

\section{METODA}

\section{Alat dan bahan}

Bahan-bahan yang akan digunakan dalam penelitian ini adalah serbuk chitosan dengan derajat deasetilisasi $85 \%$, asam asetat 1,5\% (v/v), larutan $\mathrm{NaOH} 1 \%$ (b/v), Poly (vynil) Alcohol 5\% $(\mathrm{BM}=72.000)$, dan Poly (ethilene) Glikol $(\mathrm{BM}=10.000)$. Alat-alat yang digunakan adalah pengaduk magnetik, neraca analitik, pemanas, oven, beaker glass, Erlenmeyer dan cawan petri.

\section{Sintesis membran}

Pada penelitian ini menggunakan teknik inversi fasa dengan konfigurasi datar. Pemilihan teknik inversi fasa karena dibandingkan dengan teknik lain, inversi fasa mempunyai kelebihan diantaranya mudah dilakukan, pembentukan pori dapat dikendalikan dan dapat digunakan pada berbagai macam polimer. Membran inversi fasa dapat dibuat dari berbagai macam polimer dengan syarat polimer yang digunakan harus larut pada pelarut yang sesuai atau campuran pelarut. Secara umum membran dengan teknik inversi fasa dapat dibuat menjadi dua konfigurasi yaitu datar (lembaran) atau pipa (turbular). Tahapan dasar pembuatan membran dengan teknik inversi fasa yaitu pembuatan larutan 
polimer, proses casting untuk membentuk lapisan tipis, perendaman di non pelarut di bak koagulasi dan perlakuan akhir. Membran chitosan yang dibuat dengan teknik inverse fasa dapat dikombinasikan dengan penambahan Poly (Vyvil) Alcohol sebagai bahan pembuat film dan Poly (Ethilene) Glikol sebagai bahan pembentuk pori.

Pembuatan membran dilakukan dengan mencampurkan larutan chitosan 5\% (b/V) dengan larutan Poly (vynil) Alcohol 5\% (b/V) dengan variasi penambahan Poly (vynil) Alcohol sebesar 30\%, 40\%, 50\%, 60\% dan 70\%. Larutan Chitosan 5\% (b/v) dibuat dengan melarutkan 5 gram serbuk chitosan pada larutan asam asetan 1,5\% dengan pengadukan selama 3 jam. Larutan Poly (vynil) Alcohol 5\% (b/v) dibuat dengan melarutkan Poly (vynil) Alcohol 5 gram serbuk Poly (vynil) Alcohol pada $100 \mathrm{~mL}$ air mendidih dengan pengadukan selama 3 jam. Pencampuran larutan chitosan 5\% dan Poly (vynil) Alcohol 5\% dilakukan dengan menggunakan pengaduk magnetik selama 30 menit dengan kecepatan rendah (100 rpm) dan kecepatan tinggi (300 rpm), kemudian ditambahkan Poly (ethilene) Glikol dengan konsentrasi 2,5\% (b/v). Larutan yang telah homogen selanjutnya dituangkan ke dalam cetakan (cawan petri diameter $15 \mathrm{~cm}$ ) dan dikeringkan pada suhu $80^{\circ} \mathrm{C}$ selama 24 jam hingga diperoleh film membran kering. Untuk melepas membran dari cetakan, diperlukan perendaman dengan menggunakan $\mathrm{NaOH} 1 \%$ selama 2 jam untuk menghilangkan sisa asam pada membran. Membran yang diperoleh selanjutnya dibilas dengan aquades hingga netral dan kemudian dikeringkan pada suhu ruang.

\section{Karakterisasi membran}

Karakteristik membran chitosan termodifikasi Poly (vynil) Alcohol dan Poly (ethelene) Glikol dilakukan dengan uji mekanik dan analisa morfologi menggunakan SEM (Scanning Electron Microscopy). Pengukuran sifat mekanik perlu dilakukan untuk mengetahui kekuatan membran jika dikenai kekuatan yang dapat merusak membran. Pengujian mekanik dilakukan dengan melakukan uji tarik pada sampel membran menggunakan alat autograph yang dilakukan di laboratorium dasar Fakultas farmasi, Universitas Airlangga. Uji tarik (tensile test) digunakan untuk mengetahui elastisitas membran. Kuat tarik didefinisikan sebagai besarnya gaya tarik maksimum (newton) dalam satuan luas penampang benda $\left(\mathrm{mm}^{2}\right)$. Persamaan untuk kuat tarik adalah :

$$
\mathbf{K}_{\mathbf{T}}=\mathbf{F} / A
$$

Dimana :

$\mathbf{K}_{\mathbf{T}}=$ Kuat tarik $\left(\mathrm{N} / \mathrm{mm}^{2}\right)$

$\mathbf{F}=$ Gaya tarik maksimum (newton)

$A=$ Luas penampang membran $\left(\mathrm{mm}^{2}\right)$

Kinerja membran dapat dilihat dari nilai fluks yang dihasilkan. Nilai fluks menunjukkan nilai laju alir dalam melewati membran. Pengukuran permeabilitas dilakukan dengan pengujian fluks terhadap limbah cair kelapa sawit. Pengukuran fluks dilakukan menggunakan reaktor cross flow dengan tekanan operasi 3 bar (Sari, 2014). Aplikasi filtrasi dilakukan selama 50 menit dengan permeat diambil setiap 10 menit. Membran yang telah kering dipotong berbentuk lingkaran dengan diameter $3 \mathrm{~cm}$ sesuai dengan disain reaktor. Penentuan fluks air diperoleh dengan mengukur banyaknya volum permeat yang melewati membran tiap satuan luas permukaan membran per satuan waktu. Fluks volume dinyatakan sebagai berikut:

$$
\mathbf{J}=\frac{v}{A X t}
$$

Dimana :

$$
\begin{aligned}
& \mathbf{J}=\text { Fluks }\left(\mathrm{L} / \mathrm{m}^{2} . \text { jam }\right) \\
& \mathbf{V}=\text { volume permeate }(\mathrm{ml}) \\
& \mathbf{A}=\text { Luas permukaan membran }\left(\mathrm{m}^{2}\right) \\
& \mathbf{t}=\text { Waktu (jam) }
\end{aligned}
$$

Sebelum pengukuran fluks, terlebih dahulu dilakukan kompaksi terhadap membran yang akan diuji. Kompaksi dilakukan dengan mengalirkan air melewati membran hingga diperoleh fluks air yang konstan (Farha dan Kusumawati, 2012).

Analisa morfologi membran dengan SEM yang dilakukan di Laboratorium Divisi karakterisasi material-Jurusan Teknik Material dan Metalurgi, Institut Teknologi Sepuluh Nopember. Analisa SEM sering digunakan untuk mendapatkan foto- 
foto pada skala mikron bahkan lebih kecil, distribusi dan ukuran pori-pori dapat diamati. Dalam penentuan morfologi membran, sampel membran yang akan diperiksa dengan SEM dikeringkan terlebih dahulu kemudian direndam dengan nitrogen cair selama beberapa detik hingga membran mengeras. Sampel yang telah direndam kemudian diangkat. Selanjutnya potongan sampel ini dilapisi dengan emas murni (coating) yang berfungsi sebagai penghantar pada permukaan sampel membran. Permukaan membran kemudian difoto dengan perbesaran tertentu. SEM memdeteksi elektron yang dipancarkan oleh suatu sampel ketika ditembakkan oleh berkas elektron berenergi tinggi secara kontinyu yang dipercepat di dalam elektromagnetik koil yang dihubungkan dengan sinar katode sehingga dihasilkan suatu informasi mengenai keadaan permukaan suatu sampel (Samsiah, 2009).

\section{Aplikasi filtrasi membran dengan aliran umpan cross flow}

Aliran umpan dalam filtrasi membran terdiri dari dua jenis aliran umpan, yaitu aliran cross flow dan aliran dead end. Pada penelitian ini menggunakan sistem aliran cross flow. Sistem cross flow secara teori lebih baik dari sistem dead end dimana laju aliran retentate tidak seluruhnya menjadi permeate, ada bagian yang lewat menjadi laju aliran balik pada sistem cross flow. Pada aliran dead end, aliran secara keseluruhan akan melewati membran (sebagai media dilter) dan partikel akan tertahan pada membran. Menurut Ghosh (2003), pada aliran cross flow memungkinkan partikel-partikel bahan akan mengalir rata memenuhi seluruh permukaan membran. Hal ini berbeda dengan sistem filtrasi aliran dead end atau sistem sentrifugasi berdasarkan kecepatan rotasi. Aliran cross flow (tangensial) yang melewati permukaan membran akan mengurangi terjadinya akumulasi partikelpartikel sebagai penyebab polarisasi konsentrasi dan meminimalkan terbentuknya penyumbatan pori-pori membran akibat fouling. Hal tersebut juga dipengaruhi oleh sifat bahan (ukuran partikel, berat molekul/BM, daya adhesi antar komponen), kondisi operasi (tekanan, laju alir, suhu dan waktu) dan jenis material membran. Pada aliran cross flow memungkinkan pemisahan lebih terfokus karena sistem membran akan semakin memadatkan partikel-partikel yang tertahan pada permukaan membran sehingga pemisahan lebih efisien dan optimal. Kelebihan lain dari sistem cross flow juga dapat memfasilitasi perputaran kembali konsentrat dalam tangki umpan dan mencampurkannya sebagai umpan baru.

Sebelum aplikasi filtrasi menggunakan reactor cross flow, membran yang akan diuji dipotong berbentuk lingkaran dengan diameter $\pm 4 \mathrm{~cm}$. Membran diletakkan di dalam reaktor pada tempat peletakan membran dan dipastikan dalam keadaan tertutup rapat agar tidak terjadi kebocoran. Air limbah ditampung pada bak berukuran 25 liter yang selanjutnya akan dipompa menuju reaktor cross flow dengan bantuan Booster Pump. Selanjutnya dilakukan pengaplikasian aquades pada membran selama 15 menit, agar pori-pori membran dapat bekerja lebih efektif. Larutan feed limbah POME dialirkan ke dalam alat, valve ditutup rapat hingga reaktor terisi penuh dan kemudian kedalamnya dialirkan tekanan.

\section{HASIL DAN PEMBAHASAN}

\section{Uji Morfologi}

Analisis morfologi membran menggunakan alat Scanning Electron Microscopy with Energy Dispersive X-ray Spectroscopy (SEM-EDX). Analisis SEM dilakukan untuk mengetahui poripori membran sedangkan EDX untuk mengetahui komposisi unsur yang terkandung dalam membran sebelum dan sesudah membran digunakan untuk proses filtrasi limbah cair kelapa sawit. Membran yang digunakan untuk analisis SEM dilakukan pada membran dengan konsentrasi Poly (vynil) Alcohol 50\% (v/v) dan kecepatan pengadukan $300 \mathrm{rpm}$. Morfologi penampang membran hasil analisa SEM dapat dilihat pada Gambar 1. 

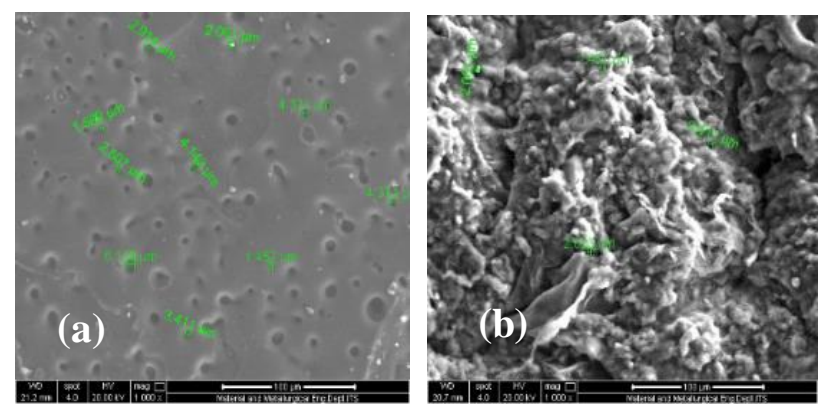

Gambar 1. Morfologi penampang membran sebelum (a) dan setelah (b) aplikasi filtrasi pada pembesaran 1000x.

Berdasarkan hasil analisa SEM membran sebelum aplikasi filtrasi (Gambar 1a) dapat dilihat bahwa ukuran pori membran hasil penelitian berkisar antara 1,4 $\mu \mathrm{m}$ hingga $6,1 \mu \mathrm{m}$ sehingga membran komposit yang telah dibuat dapat digolongkan dalam kategori membran mikrofiltrasi. Gambar 1 menunjukkan foto hasil analisa SEM membran sebelum dan sesudah aplikasi filtrasi pada limbah cair kelapa sawit terlihat adanya perberbedaan. Sebelum aplikasi filtrasi pori-pori membran berkisar antara 1,4-6,1 $\mu \mathrm{m}$, sedangkan setelah aplikasi filtrasi pori-pori membran mengecil berkisar antara 1,1-3,4 $\mu \mathrm{m}$ dan terlihat bahwa pori-pori membran semakin berkurang, hal ini dikarenakan telah terjadi fouling pada membran sehingga pori-pori tertutup oleh polutan-polutan yang tidak lolos dan tertahan pada pori membran.

Citra penampang membran setelah aplikasi filtrasi terlihat bahwa permukaan membran semakin memadat dibandingkan dengan foto SEM sebelum membran digunakan. Berdasarkan penelitian Sari (2014), membran terlihat semakin padat disebabkan karena terjadinya fouling. Fouling menyebabkan terjadinya penyumbatan pori-pori pada membran karena penumpukan material polutan pada permukaan membran. Fouling pada membran tidak hanya terjadi di permukaan atas atau lapisan luar membran saja yang membentuk cake tetapi juga lapisan dalam membran. Polutan yang masuk ke dalam lapisan dalam tersebut terjadi akibat adanya tekanan yang diberikan selama operasi membran. Tekanan akan mendorong deposisi partikel pada permukaan membran. Hal ini juga didukung dengan citra SEM pada penampang melintang.

Pada Gambar 2 terlihat bahwa sebelum aplikasi filtrasi terlihat struktur pori membran sedangkan setelah aplikasi filtrasi terlihat bahwa pori membran mengalami kerusakan karena masuknya polutan pada pori-pori bagian dalam membran. Setelah proses filtrasi dapat terlihat bahwa polutan-polutan pada limbah cair kelapa sawit tidak hanya mengisi permukaan membran tetapi juga pori-pori membran bagian dalam, hal ini membuktikan bahwa proses filtrasi tidak hanya melibatkan adsorpsi (surface sorption) pada bagian permukaan membran tetapi juga terjadi absorpsi (internal sorption) pada bagian dalam membran (Gambar 2b).

Mekanisme adsorpsi dan absorpsi yang terjadi antara membran komposit chitosan dengan limbah umpan melibatkan gugus - $\mathrm{NH} 2$ yang dimiliki oleh chitosan yang akan berubah menjadi -NH3+ dalam suasana asam (Chatterjee et al., 2009).
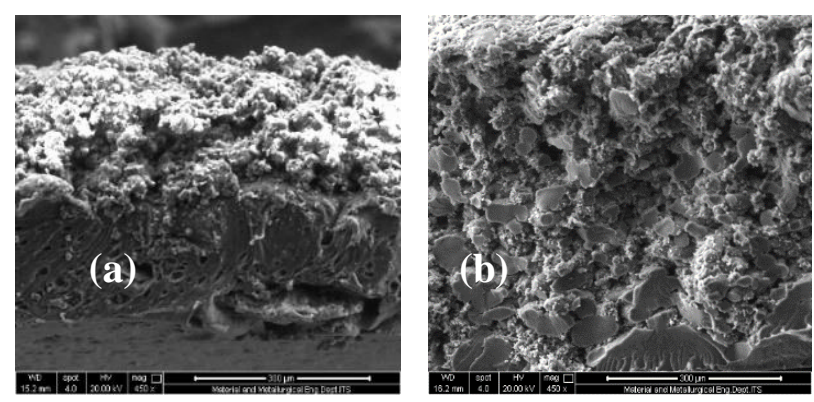

Gambar 2. Morfologi penampang melintang membran sebelum filtrasi (a) dan setelah filtrasi (b) pada pembesaran 450x.

SEM EDX digunakan untuk mengetahui komponen unsur yang terdapat pada membran. Komposisi unsur yang terkandung pada membran sebelum dan setelah filtrasi dapat dilihat pada Tabel 1. 
Tabel 1. Komposisi unsur membran sebelum dan setelah aplikasi filtrasi.

\begin{tabular}{ccc}
\hline $\begin{array}{c}\text { Unsur } \\
\text { komponen } \\
\text { membran }\end{array}$ & \multicolumn{2}{c}{$\% \mathbf{W}$} \\
\cline { 2 - 3 } & sebelum & sesudah \\
\hline $\mathrm{C}$ & 53,94 & 60,26 \\
$\mathrm{O}$ & 46,06 & 34,75 \\
$\mathrm{Mg}$ & - & 0,40 \\
$\mathrm{Al}$ & - & 0,76 \\
$\mathrm{Si}$ & - & 1,50 \\
$\mathrm{P}$ & - & 0.90 \\
$\mathrm{~S}$ & - & 0,36 \\
$\mathrm{Cl}$ & - & 0,36 \\
$\mathrm{~K}$ & - & 0,18 \\
$\mathrm{Ca}$ & - & 0,28 \\
$\mathrm{Fe}$ & - & 0,26 \\
\hline
\end{tabular}

Tabel 1 menunjukkan hasil analisis komposisi unsur rata-rata dari ketiga titik pada membran sebelum dan sesudah aplikasi filtrasi. Berdasarkan hasil analisis sebelum membran digunakan untuk mengolah air limbah POME, terkandung unsur $\mathrm{C}$ sebesar $53.94 \%$ dan $\mathrm{O}$ sebesar $46,06 \%$. Unsur unsur tersebut berasal dari bahan utama pembuatan membran dan bahan pendukung membran. Bahan utama pembuatan membran adalah chitosan yang mengandung unsur $\mathrm{C}$ (karbon), $\mathrm{H}$ (hidrogen), $\mathrm{N}$ (nitrogen) dan $\mathrm{O}$ (oksigen) dan bahan pendukung yaitu Poly (vynil) Alcohol dan Poly (ethilene) Glikol yang mengandung unsur C (karbon), $\mathrm{H}$ (hidrogen) dan O (oksigen).

Setelah aplikasi filtrasi di dalam membran terdapat unsur unsur lain yaitu $\mathrm{Mg}$ sebesar $0,4 \%$, Al sebesar $0,76 \%$, Si sebesar 1,5\%, P sebesar $0.9 \%, \mathrm{~S}$ sebesar $0,36 \%, \mathrm{Cl}$ sebesar $0,36 \%, \mathrm{~K}$ sebesar $0,18 \%$, Ca sebesar $0.28 \%$ dan Fe sebesar 0,26\%. Pada hasil analisis SEM EDX membran setelah digunakan untuk filtrasi limbah POME terdapat terdapat kandungan unsur $\mathrm{Mg}, \mathrm{Al}, \mathrm{Si}, \mathrm{P}$, $\mathrm{S}, \mathrm{Cl}, \mathrm{K}, \mathrm{Ca}$ dan $\mathrm{Fe}$, unsur-unsur tersebut berasal dari polutan limbah POME yang tidak lolos dan terjebak dalam pori membran.
Pengaruh Konsentrasi Poly (vynil) Alcohol dalam campuran Membran dan Kecepatan Pengadukan terhadap Sifat Mekanik Membran

Perubahan nilai Modulus Elastisitas Young membran untuk setiap variasi konsentrasi Poly (vynil) Alcohol dan kecepatan pengadukan ditunjukkan pada Gambar 3.

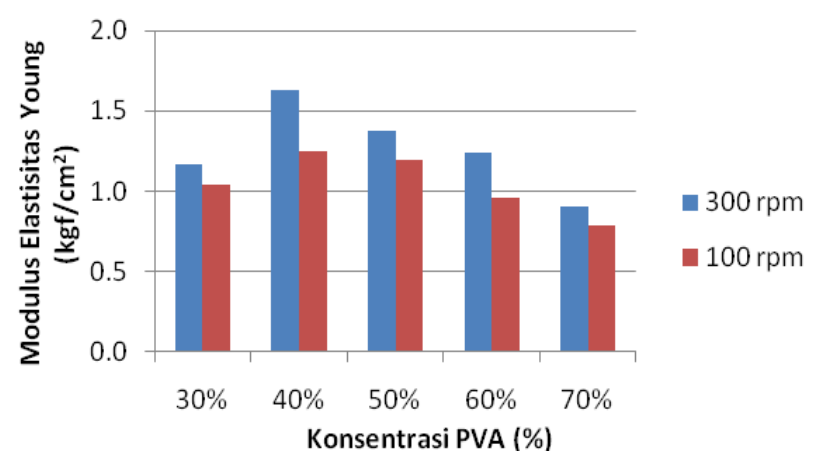

Gambar 3. Perubahan nilai Modulus Elastisitas Young pada variasi konsentrasi Poly (vynil) Alcohol dan kecepatan pengadukan.

Nilai kuat tekan membran dengan variasi kecepatan pengadukan $100 \mathrm{rpm}$ secara berturutturut adalah $0,791 \mathrm{kgf} / \mathrm{cm}^{2} ; 0,962 \mathrm{kgf} / \mathrm{cm}^{2} ; 1,194$ $\mathrm{kgf} / \mathrm{cm}^{2} ; 1,247 \mathrm{kgf} / \mathrm{cm}^{2}$ dan $1,038 \mathrm{kgf} / \mathrm{cm}^{2}$ dan untuk variasi kecepatan $300 \mathrm{rpm}$ masing-masing sebesar $0,905 \mathrm{kgf} / \mathrm{cm}^{2} ; 1,240 \mathrm{kgf} / \mathrm{cm}^{2} ; 1,380$ $\mathrm{kgf} / \mathrm{cm}^{2} ; 1,633 \mathrm{kgf} / \mathrm{cm}^{2}$ dan $1,165 \mathrm{kgf} / \mathrm{cm}^{2}$. Kekuatan elastisitas membran pada kecepatan pengadukan tinggi $(300 \mathrm{rpm})$ lebih besar dibandingkan dengan kecepatan rendah (100 rpm), hal ini disebabkan karena pada kecepatan pengadukan $300 \mathrm{rpm}$, ikatan dan reaksi pengadukan antara chitosan, Poly (vynil) Alcohol dan Poly (ethilene) Glikol lebih sempurna dan menghasilkan pori yang rapat sehingga kekuatan tarik membran lebih besar dibandingkan dengan kecepatan pengadukan 100 rpm. Reaksi kimia terjadi ketika partikel-partikel bertabrakan. Kecepatan reaksi meningkat jika terjadi lebih banyak tabrakan setiap detiknya. Pengadukan yang cepat menjadikan partikel-partikel zat bergerak dan bersentuhan dengan partikel 
lainnya sehingga reaksi dapat berjalan dengan lebih cepat sehingga mengakibatkan semakin banyak zat yang terlarut (Atkins, 1998). Drastinawati dan Zultiniar (2013) dalam penelitiannya menyatakan bahwa semakin besar kecepatan pengadukan maka reaksi adsorpsi logam $\mathrm{Cu}^{2+}$ semakin besar.

Berdasarkan Gambar 3, nilai kuat tekan membran terbesar didapatkan pada membran dengan konsentrasi Poly (vynil) Alcohol sebesar $40 \%$ kecepatan pengadukan $300 \mathrm{rpm}$ yaitu sebesar $1,633 \mathrm{kgf} / \mathrm{cm}^{2}$. Berdasarkan grafik tersebut dapat dilihat bahwa kekuatan membran meningkat dengan meningkatnya konsentrasi Poly (vynil) Alcohol baik pada pengadukan rendah (100 rpm) maupun pengadukan tinggi (300 rpm). Pada konsentrasi 40\% komposisi chitosan, Poly (vynil) Alcohol dan Poly (ethilene) Glikol mencapai komposisi optimal dalam pembentukan material yang kuat dan elastis. Pada konsentrasi 30\% hingga 40\% kuat tarik mengalami kenaikan, sedangkan pada konsentrasi $40 \%$ hingga $70 \%$ nilai elastisitas membran menurun karena membran pada komposisi ini telah didominasi perilaku plastik yang tinggi sehingga kekuatan tarik yang dihasilkan rendah dan kekuatan regangnya sangat tinggi.

Setiawan et al. (2015) melaporkan bahwa kuat tekan pada membran selulosa chitosan dengan konsentrasi chitosan 9\% dan lama pengadukan 48 jam yang mampu dicapai sebesar 3, 86 $\mathrm{kgf} / \mathrm{cm}^{2}$. Rohman et al. (2009) dalam penelitiannya menyebutkan bahwa struktur dan pori membran dipengaruhi oleh massa polimer dalam pembuatan larutan chitosan. Sehingga semakin besar konsentrasi polimer hingga titik tertentu akan menghasilkan membran dengan struktur permukaan yang lebih baik, kemudian akan terjadi penumpukkan padatan pada suatu bagian dari membran jika konsentrasi larutan ditingkatkan akan menimbulkan adanya bagian yang cacat pada membran sehingga mempengaruhi kualitas membran.

\section{Pengaruh konsentrasi membran dan kecepatan pengadukan terhadap nilai fluks}

Nilai fluks adalah jumlah volume permeate yang melewati satuan luas permukaan membran pada waktu tertentu dengan adanya gaya dorong berupa tekanan. Nilai fluks membran adalah fungsi dari ukuran pori, porositas dan struktur membran. Nilai fluks mempengaruhi efisiensi pemisahan pada proses membran yang tergantung pada struktur membran seperti distribusi ukuran pori, bentuk pori dan porositas. Nilai fluks untuk setiap variasi konsentrasi Poly (vynil) Alcohol dan kecepatan pengadukan ditunjukkan pada Tabel 2.

Tabel 2. Nilai fluks pada variasi konsentrasi Poly (vynil) Alcohol dan kecepatan pengadukan.

\begin{tabular}{|c|c|c|c|}
\hline \multirow{2}{*}{$\begin{array}{c}\text { Konsentrasi } \\
\text { Poly (vynil) } \\
\text { Alcohol }\end{array}$} & \multirow{2}{*}{$\begin{array}{c}\text { Menit } \\
\text { ke }\end{array}$} & \multicolumn{2}{|c|}{ Nilai fluks $\left(\mathrm{L} / \mathrm{m}^{2}\right.$. jam $)$} \\
\hline & & $300 \mathrm{rpm}$ & $100 \mathrm{rpm}$ \\
\hline \multirow{5}{*}{$30 \%$} & 10 & 27.15 & 40.20 \\
\hline & 20 & 24.08 & 33.30 \\
\hline & 30 & 22.27 & 31.08 \\
\hline & 40 & 21.32 & 25.24 \\
\hline & 50 & 19.73 & 20.79 \\
\hline \multirow{5}{*}{$40 \%$} & 10 & 20.68 & 37.44 \\
\hline & 20 & 19.20 & 34.26 \\
\hline & 30 & 15.80 & 29.70 \\
\hline & 40 & 13.68 & 24.18 \\
\hline & 50 & 12.52 & 19.09 \\
\hline \multirow{5}{*}{$50 \%$} & 10 & 17.18 & 24.18 \\
\hline & 20 & 16.23 & 21.74 \\
\hline & 30 & 14.74 & 18.98 \\
\hline & 40 & 13.47 & 14.21 \\
\hline & 50 & 11.45 & 11.45 \\
\hline \multirow{5}{*}{$60 \%$} & 10 & 24.18 & 30.12 \\
\hline & 20 & 20.36 & 28.64 \\
\hline & 30 & 18.24 & 23.55 \\
\hline & 40 & 14.11 & 19.94 \\
\hline & 50 & 12.20 & 17.18 \\
\hline \multirow{5}{*}{$70 \%$} & 10 & 25.24 & 31.39 \\
\hline & 20 & 20.79 & 28.64 \\
\hline & 30 & 16.23 & 26.94 \\
\hline & 40 & 12.41 & 25.88 \\
\hline & 50 & 11.03 & 25.14 \\
\hline
\end{tabular}


Berdasarkan pada Tabel 2, semakin lama waktu pengoperasian maka semakin kecil nilai fluks yang dihasilkan. Nilai fluks terendah dihasilkan oleh membran dengan konsentrasi Poly (vynil) Alcohol sebesar $70 \%$ di menit ke 50 yaitu sebesar $11,03 \mathrm{~L} / \mathrm{m}^{2}$.jam Pada 10 menit pertama nilai fluks membran sebesar $25,24 \mathrm{~L} / \mathrm{m}^{2}$.jam dan terus menurun hingga menit ke 50 menjadi 11,03 $\mathrm{L} / \mathrm{m}^{2}$.jam. Nilai fluks tertinggi didapatkan pada membran RCS70VA30 di menit ke 10 yaitu sebesar 40,20 L/m ${ }^{2}$.jam dan terus menurun hingga $20,79 \mathrm{~L} / \mathrm{m}^{2}$.jam pada menit ke 50 . Mekanisme penurunan nilai fluks membran komposit chitosan dengan bertambahnya waktu operasi dalam proses filtrasi disebabkan oleh penurunan porositas membran karena penutupan pori membran (Zulfi et al., 2014). Hal ini dikarenakan terjadinya fouling pada membran yang disebabkan oleh adanya adsorpsi polutan limbah ke dalam membran, sehingga partikelpartikel terakumulasi dan membentuk suatu lapisan pada bagian permukaan membran dan pori dalam membran yang akan menyebabkan jumlah umpan yang mampu melewati membran berkurang sehingga nilai fluks membran turun (Sari, 2014).

Perbedaan nilai fluks juga terjadi pada variasi konsentrasi Poly (vynil) Alcohol (Tabel 2). Terlihat pada konsentrasi 30\% hingga 50\% nilai fluks mengalami penurunan dengan penambahan konsentrasi Poly (vynil) Alcohol sedangkan pada konsentrasi $50 \%$ hingga $70 \%$ nilai fluks mengalami kenaikan. Hal ini dapat diakibatkan karena pada konsentrasi $30 \%$ hingga mencapai $50 \%$ penambahan konsentrasi Poly (vynil) Alcohol mencapai komposisi terbaik dengan chitosan dan Poly (ethilene) Glikol sebagai bahan pendukung membran yang berfungsi membentuk film sehingga pori-pori membran terbentuk rapat, sedangkan dengan kenaikan konsentrasi lebih maka penambahan Poly (vynil) Alcohol akan memperbesar pori. Berdasarkan nilai fluks membran chitosan pada Tabel 2 dengan pembagian nilai tekanan operasi yaitu sebesar 3 bar, maka didapatkan nilai fluks per tekanan operasi berkisar 3,7-13,4 L/m².jam.bar sehingga dapat disimpulkan bahwa membran komposit chitosan, Poly (vynil) Alcohol dan Poly (ethilene) Glikol yang telah dibuat termasuk membran ultrafiltrasi.

\section{KESIMPULAN}

Berdasarkan penelitian yang telah dilakukan didapatkan beberapa kesimpulan bahwa variasi kecepatan pengadukan dan konsentrasi Poly (vynil) Alcohol dalam campuran memberikan pengaruh terhadap karakteristik membran komposit yang terbentuk. Kuat tarik membran terbesar pada variasi kecepatan pengadukan 100 rpm dan $300 \mathrm{rpm}$ didapatkan pada membran dengan konsentrasi Poly (vynil) Alcohol sebesar $40 \%(\mathrm{v} / \mathrm{v})$. Kekuatan tarik pada saat putus meningkat dengan meningkatnya konsentrasi Poly (vynil) Alcohol, dan pada konsentrasi 50$70 \%$ (v/v) mengalami penurunan. Kekuatan elastisitas membran pada kecepatan pengadukan 300 rpm lebih besar dibandingkan dengan kecepatan 100 rpm. Nilai fluks tertinggi didapatkan pada variasi konsentrasi membran $30 \%(\mathrm{v} / \mathrm{v})$, kecepatan pengadukan $100 \mathrm{rpm}$ yaitu sebesar 40,20 L/m².jam. Berdasarkan nilai fluks persatuan tekanan yang digunakan yaitu berkisar antara 3-14 L/m².jam.bar dapat disimpulkan bahwa membran komposit yang telah dibuat termasuk dalam membran ultrafiltrasi.

\section{UCAPAN TERIMA KASIH}

Penulis mengucapkan terima kasih kepada Direktorat Pendidikan Tinggi, Departement Pendidikan dan Kebudayaan Republik Indonesia yang telah memberikan dukungan finansial melalui beasiswa Fresh Graduate tahun 20142015 serta seluruh pihak yang mendukung dan membantu penelitian dalam jurnal ini.

\section{DAFTAR PUSTAKA}

Atkins, PW. (1998). Physical Chemistry, $6^{\text {th }}$ Edd. Oxford: Oxford University Press

Chatterjee, S., D.S. Lee, M.W. Lee dan S.H. Woo. (2009). Congo red Adsorption from aqueous solution by using chitosan hydrogel beads impregnated with nanionic surfactant. Korea: Bioresource technology 100. 
Cheng, Z., X. Liu, M. Han dan M. Wang. (2010). Adsorption kinetic character of copper ions onto a modified chitosan transparent thin membran from aqueous solution. Journal Hazard Mater, (182): 408-415.

Dash, M., F. Chiellini, R. M. Ottenbrite dan E. Chiellini. (2011). Chitosan-a versatile semisynthetic polymer in biomedical applications. Journal Polymer Science, (36): 981-1014.

Drastinawati, dan Zultiniar. (2013). Pengaruh Kecepatan Pengadukan dan Temperatur terhadap Konstanta Kecepatan Adsorpsi $\mathrm{Cu} 2+$ dengan Arang Aktif Cangkang Sawit Sisa Pembuatan Asap Cair. Jurnal Ilmiah Sains Terapan. 4(1):47-53.

Farha, I. F. dan N. Kusumawati. (2012). Pembuatan membran komposit chitosanPVA dan pemanfaatannya pada pemisahan limbah pewarna Rhodamin-B. Prosiding Seminar Nasional Kimia UNESA, C69-C75.

Ghosh, R. (2003). Protein Bioseparation Using Ultrafiltration : Theory, Applications and New Developments. London : Imperial College Press, 105 - 109

Horimatsu, N., T. Takahashi, D. Kobayashi, A. Shono dan K. Otake. (2013). Development of polystyrene sulfonate/ glycol chitosan hybrid membran for direct methanol fuel cell, Journal Desalination Water Treatment, (51): 5254-5259.

Huang, R. H., G. H. Chen, M. K. Sun dan C. J. Gao. (2009). Preparation and characterization of composite NF membran from a graft copolymer of trimethylallyl ammonium chloride onto chitosan by toluene diisocyanate cross-linking, Journal Desalination, (239): 38-45

Liu, Y. L., Y. H. Su, K.R. Lee dan J.Y. Lai. (2005). Crosslinked organic-inorganic hybrid chitosan membrans for pervaporation dehydration of isopropanol-water mixtures with along-term stability. Journal Membran Science, (251): 233-238.

Meriatna. (2008). Penggunaan Membran Kitosan untuk Menurunkan Kadar Logam Krom $(\mathrm{Cr})$ dan Nikel (Ni) dalam Limbah Cair Industri Pelapisan Logam. Tesis. Jurusan Teknik Kimia Universitas Sumatra Utara.

Rohman, T., U.B.L. Utami dan Mahmud. (2009). Pengaruh Konsentrasi Chitosan terhadap Karakter Membran Chitosan. Jurnal Sains dan Terapan Kimia. 2(1)14-24

Samsiah, R. (2009). Karakterisasi Biokomposit Apatit-Chitosan dengan XRD (X-Ray Diffraction), FTIR (Fourier Transform Infrared), SEM (Scanning Electron Microscop), dan Uji Mekanik. Skripsi, Fakultas Teknologi Pertanian, Institut Petanian Bogor.

Sari, T. K. (2014). Pengolahan Limbah Laundry Menggunakan Membran Nanofiltrasi Zeolit Aliran Cross Flow untuk Filtrasi Kekeruhan dan Fosfat. Skripsi. Jurusan Teknik Lingkungan, ITS, Surabaya.

Setiawan, D.A, B.D. Argo dan Y. Hendrawan. (2015). Pengaruh Konsentrasi dan Preparasi terhadap Karakterisasi Membran Chitosan. Jurnal Keteknikan Pertanian Tropis dan Biosistem. 3(1) : 95-99.

Shen, J.N., C. C. Yu, G.N. Zeng dan B.V.D. Bruggen. (2013). Preparation of a facilitated transport membran composed of carboxymethyl chitosan and polyethylenimine for $\mathrm{CO}_{2} / \mathrm{N}_{2}$ separation, Int. J. Mol. Sci. (14): 3621-3638.

Zeng, M.F. dan Z.P. Fang. (2004a). Preparation of sub-micrometer porous membran from chitosan/ polyethylene glycol semi-IPN, Journal Membran Science, (245): 95-102.

Zeng, M.F., Z.P. Fang dan C.W. Xu. (2004b). Novel method of preparing microporous membran by selective dissolution of 
chitosan/polyethylene glycol blend membran, Journal Application Polymer Science, (91): 2840-2847.

Zhao, Q., Q.F. An, Y.L. Ji, J.W. Qian dan C.J. Gao. (2011). Polyelectrolyte complex membrans for pervaporation, nanofiltration and fuel cell applications, Journal Membran Science, (379): 19-45

Zulfi, F., K.Dahlan dan P. Sugita. (2014). Karakteristik fluks membran dalam proses filtrasi limbah cair industry pelapisan logam. Jurnal Biofisika. 10 (1): 19-29 